\section{RET-oncogene-targeting drugs draw notice}

Two biotechs with drug candidates targeting the RET oncogene, a 'driver' gene in human cancers, presented encouraging early data at the International Association for the Study of Lung Cancer meeting in Chicago in September. The preliminary lung cancer results from San Diego-based Mirati Therapeutics and Stamford, Connecticut-based Loxo Oncology are fuelling hopes that targeting fusions and mutations in the RET (rearranged during transfection) gene could benefit patients who have acquired resistance mechanisms to therapeutic agents and potentially enhance responses to anti-PD-1 agents. Mirati presented early data from two ongoing studies of sitravatinib, its multikinase inhibitor, whose targets include RET, MET, Trk and other key cell growth regulators. One of them, a single-agent study, showed tumor reduction in four non-small-cell lung cancer (NSCLC) patients with RET fusion mutations. The other study is evaluating the drug in combination with the anti-PD-1 checkpoint inhibitor Opdivo (nivolumab), a Bristol-Myers Squibb drug. Findings so far suggest that RET inhibition enhances antitumor immune responses by altering the tumor microenvironment, and making the body more receptive to treatment with Opdivo. Loxo demonstrated proof of concept for its Loxo292 selective RET inhibitor, obtaining partial responses in two patients who had progressed after treatment with multi-tyrosine-kinase inhibitors. The companies are focusing their development efforts on NSCLC patients with rare genetic alterations in the RET proto-oncogene. The oncogene encodes a receptor tyrosine kinase involved in extracellular signaling but, when mutated, can give rise to cancers. RET gene fusions and mutations have been identified in approximately $2 \%$ of NSCLC, $10-20 \%$ of papillary thyroid cancer, and a subset of colon and other cancers. RET point mutations account for approximately $60 \%$ of medullary thyroid cancer. Both cancers associated with RET fusions and select cancers associated with RET mutations depend primarily on this single activated kinase for their proliferation and survival, according to Loxo. Several approved multi-tyrosine-kinase inhibitors targeting RET are in trials in lung cancer, including South San Francisco-based Exelixis's Cabometyx (cabozantinib) and Cambridge, UK-based AstraZeneca's Caprelsa (vandetanib). In addition to Loxo-292, more selective RET inhibitors include RXDX-105 from Ignyta, in San Diego, and Cambridge, Massachusetts-based Blueprint Medicines' BLU-667. Inhibitors of ALK (anaplastic lymphoma kinase), such as Basel, Switzerland-based Roche's Alecensa (alectinib), also have documented clinical activity against RET fusions in NSCLC.

"They didn't just win the Nobel Prize, they revolutionized the field." Wired Science tweeted about the three chemists, Jacques Dubochet, Joachim Frank and Richard Henderson. who won the Nobel Prize for their work on cryo-electron microscopy. 99 (Wired, 4 October 2017)

Table 1 Transthyretin amyloidosis drugs in development

\begin{tabular}{|c|c|c|c|}
\hline Molecule & Developer & Mechanism & Status \\
\hline Diflunisal & Not applicable ${ }^{a}$ & $\begin{array}{l}\text { Transthyretin stabilizer, which } \\
\text { reduces the rate of tetramer dis- } \\
\text { sociation }\end{array}$ & $\begin{array}{l}\text { Used off-label after a phase } 2 \text { trial } \\
\text { showed that it slowed progression } \\
\text { in patients with hereditary trans- } \\
\text { thyretin (hATTR) amyloidosis }\end{array}$ \\
\hline $\begin{array}{l}\text { Vyndaqel (tafa- } \\
\text { madis) }\end{array}$ & Pfizer (New York) & $\begin{array}{l}\text { Transthyretin stabilizer, which } \\
\text { reduces the rate of tetramer dis- } \\
\text { sociation }\end{array}$ & $\begin{array}{l}\text { Approved in the EU Nov. 17, } \\
2011 \text { for hATTR amyloidosis with } \\
\text { stage } 1 \text { polyneuropathy; in phase } \\
3 \text { trials for treating transthyretin } \\
\text { cardiomyopathy in the US }\end{array}$ \\
\hline $\begin{array}{l}\text { Patisiran (ALN- } \\
\text { TTR02) }\end{array}$ & $\begin{array}{l}\text { Alnylam, Sanofi } \\
\text { Genzyme }\end{array}$ & $\begin{array}{l}\text { Lipid-nanoparticle- } \\
\text { encapsulated double-stranded } \\
\text { siRNA targeting a } 3^{\prime} \text { untrans- } \\
\text { lated region of mutant and wild- } \\
\text { type transthyretin mRNA }\end{array}$ & $\begin{array}{l}\text { Met the primary endpoint of a } \\
\text { phase } 3 \text { trial in patients with } \\
\text { hereditary transthyretin (hATTR) } \\
\text { amyloidosis with polyneuropathy; } \\
\text { US new drug application due in } \\
2017 \text {; EU marketing authorization } \\
\text { application due in } 2018\end{array}$ \\
\hline Inotersen & Ionis & $\begin{array}{l}\text { Antisense oligonucleotide that } \\
\text { binds mRNA of wild-type and } \\
\text { mutant forms of transthyretin }\end{array}$ & $\begin{array}{l}\text { Met the co-primary endpoints of } \\
\text { a phase } 3 \text { study in patients with } \\
\text { hATTR amyloidosis with poly- } \\
\text { neuropathy; US and EU filings } \\
\text { planned for } 2017\end{array}$ \\
\hline $\begin{array}{l}\text { Miridesap } \\
\text { (GSK2315698) } \\
+ \text { dezamizumab } \\
\text { (GSK2398852) }\end{array}$ & GlaxoSmithKline & $\begin{array}{l}\text { Small-molecule depleter of } \\
\text { serum amyloid P (SAP) com- } \\
\text { ponent administered in com- } \\
\text { bination with a mAb that also } \\
\text { targets SAP }\end{array}$ & $\begin{array}{l}\text { Phase } 2 \text { underway in patients } \\
\text { with cardiac myopathy due } \\
\text { either to wild-type or heredi- } \\
\text { tary transthyretin amyloi- } \\
\text { dosis or to immunoglobulin } \\
\text { light-chain amyloidosis }\end{array}$ \\
\hline $\begin{array}{l}\text { CRX-1008 } \\
\text { (SOM-0226) }\end{array}$ & $\begin{array}{l}\text { Corino } \\
\text { Therapeutics (New } \\
\text { York), SOM Biotech } \\
\text { (Barcelona, Spain) }\end{array}$ & $\begin{array}{l}\text { Transthyretin aggregation } \\
\text { inhibitor approved as Tasmar } \\
\text { (tolcapone), a catechol-O- } \\
\text { methyltransferase inhibitor, in } \\
\text { Parkinson's disease }\end{array}$ & Phase 2a completed \\
\hline ALN-TTRsc02 & Alnylam & $\begin{array}{l}\mathrm{N} \text {-acetylgalactosamine } \\
\text { (GalNAc)-conjugated siRNA- } \\
\text { targeting mutant and wild-type } \\
\text { transthyretin mRNA }\end{array}$ & $\begin{array}{l}\text { Phase } 1 \text { completed, phase } 3 \\
\text { planned } 2018\end{array}$ \\
\hline PRX004 & Prothena & $\begin{array}{l}\text { mAb that selectively binds and } \\
\text { clears misfolded forms of trans- } \\
\text { thyretin }\end{array}$ & $\begin{array}{l}\text { Preclinical, phase } 1 \text { planned } \\
2018\end{array}$ \\
\hline $\begin{array}{l}\text { Ligand- } \\
\text { conjugated } \\
\text { antisense fol- } \\
\text { low-on version }\end{array}$ & Ionis & $\begin{array}{l}\text { GalNac-conjugated antisense } \\
\text { oligonucleotide-targeting } \\
\text { mutant and wild-type trans- } \\
\text { thyretin mRNA }\end{array}$ & $\begin{array}{l}\text { Preclinical, phase } 1 \text { planned late } \\
2018\end{array}$ \\
\hline
\end{tabular}

of inotersen

${ }^{a}$ Generic drug originally developed in the 1970 s as a non-steroidal anti-inflammatory drug.

Sources: Clinicaltrials.gov, EMA.europa.eu, PubMed, ChemSpider, company websites

that hitting production of transthyretin could not only slow or halt disease progression but could also improve patients' clinical status. It lowered patients' mean and median scores on the 304-point modified neuropathy impairment score (mNIS+7), the primary outcome measure of the trial, and on the Norfolk Quality of Life QuestionnaireDiabetic Neuropathy (Norfolk QOL-DN), the trial's key secondary outcome measure. On the mNIS+7 scale, patisiran was superior to placebo regardless of the patients' genotype, race, gender, age, baseline status, previous drug exposure or geographic location. It also bettered placebo across several other secondary endpoints that assessed muscle strength, disability, walking ability and reflexes.

At this point, there is no direct evidence to suggest that long-term shutdown of trans- thyretin production will confer a survival benefit on patients, but there are grounds for optimism. Patient deaths in the drug treatment and control arms were $4.7 \%$ and $7.8 \%$, respectively, although the study was not powered to demonstrate a survival benefit. "In all forms of systemic amyloidosis in which amyloid fibril precursor protein production has been sustainably reduced, amyloid accumulation is halted and organ or tissue function is stabilized or improved," Pepys says. "It is therefore very likely that the same will be observed in ATTR amyloidosis, and that this will translate into prolonged survival." Many patients from the Apollo study have now moved onto an open-label extension study for long-term observation. "We will be assessing mortality carefully, obviously," says Akshay Vaishnaw, executive vice president for $\mathrm{R} \& \mathrm{D}$ at Alnylam. 